\title{
Perencana yang Profesional dan Modern: Meningkatkan Peran Perencana dalam kerangka Perspektif Jangka Panjang Penjabaran Visi Indonesia 2045
}

\author{
Dadang Solihin ${ }^{1}$ \\ Pemerintah Provinsi DKI Jakarta - Indonesia
}

\begin{abstract}
This policy paper carries the theme: Towards Professional Planners in the Termination of Stages of RPJPN 2005-2025 and Determination of Strategy for Implementing Indonesia's Vision 2045. With Sub-themes: Increasing the Role of Planners in the Long-Term Perspective Framework for the Indonesian Vision 2045. It is concluded that there are three problems faced in increasing the role of planners in the framework of the elaboration of the Indonesian Vision 2045, as well as in preparing policy recommendations to realize professional planners. The three problems are the lack of understanding of JFP regulations, the existence of "minor" opinions on JFP, and a lack of leadership commitment. To overcome these three problems, the authors propose four alternative policies and three types of recommendations to be carried out by the parties in a planned and coordinated manner. This policy paper recommends that to deal with the VUCA phenomenon, a planner must be visionary, innovative and agile. Furthermore, with the enactment of the Industrial Revolution 4.0 and beyond, professional planners are required to have six abilities, namely: Complex Problem Solving, Social Skills, Process Skills, System Skills, Digital Skills, and Cognitive Abilities.
\end{abstract}

Keywords: JFP, bappenas, vision 2045, vuca, pusbindiklatren, ap2i

\footnotetext{
1 Dadang Solihin adalah Deputi Gubernur DKI Jakarta Bidang Budaya dan Pariwisata. E-mail:
} dadangsol@gmail.com 


\title{
Perencana yang Profesional dan Modern: Meningkatkan Peran Perencana dalam kerangka Perspektif Jangka Panjang Penjabaran Visi Indonesia 2045
}

\author{
Dadang Solihin
}

\section{Pendahuluan}

\subsection{Gambaran Umum}

Policy Paper ini mengusung tema: Menuju Perencana yang Profesional dalam Rangka Pengakhiran Tahapan RPJPN 2005-2025 dan Penetapan Strategi Pelaksanaan Visi Indonesia 2045. Dengan Sub-tema: Meningkatkan Peran Perencana dalam Kerangka Perspektif Jangka Panjang Penjabaran Visi Indonesia 2045.

Visi Indonesia 2045 "Berdaulat, Maju, Adil, dan Makmur"2 ditandai dengan berlakunya megatrend dunia 2045, termasuk diantaranya adalah tren perubahan teknologi yang didominasi oleh teknologi informasi dan komunikasi, bioteknologi dan rekayasa genetik, wearable devices, energi terbarukan, otomatisasi, dan artificial intelligence.

Untuk menghadapi megatrend tersebut, diperlukan Pilar Pembangunan Indonesia 2045 yang terdiri dari 1) Manusia Indonesia unggul, berbudaya, dan menguasai iptek, 2) Ekonomi maju dan berkelanjutan, 3) Pembangunan merata dan inklusif, dan 4) Negara demokratis, kuat, dan bersih.

Tantangan bagi JFP adalah bagaimana meningkatkan peran perencana dalam kerangka perspektif jangka panjang penjabaran Visi Indonesia 2045 serta bagaimana mewujudkan perencana yang profesional.

\subsection{Latar Belakang}

Fenomena VUCA ${ }^{3}$ yang sedang berlangsung saat ini, yaitu keadaan yang penuh gejolak (Volatility), tidak pasti (Uncertainty), rumit (Complexity), dan serba kabur (Ambiguity) menuntut SDM perencana yang profesional untuk memiliki minimal tiga kompetensi guna merespons perubahan yang sedemikian pesat ini. Yang pertama adalah visioner. Keadaan yang penuh gejolak (volatility) hanya bisa diredam apabila perencana memiliki visi yang jelas dan dapat diwujudkan.

Kedua, inovatif. Revolusi teknologi informasi membuat sesuatu menjadi tidak pasti (uncertainty) dan serba kabur (ambiguity). Kekuatan bisnis masa lalu, dimana harus tepat dalam perencanaan dan peramalan (forecasting) mengalami degradasi. Yang sudah direncanakan dengan baik dan diramalkan berbasis pada data-data yang sahih, bisa sekejap menjadi berantakan manakala muncul bisnis sejenis dengan platform berbeda yang jauh lebih murah dan mudah diakses konsumen. Tugas perencana untuk mengantisipasi dengan satu kata kunci: inovasi. Yang ketiga adalah lincah bergerak. Lincah adalah strategi yang sangat ampuh untuk menjawab kerumitan (complexity) dalam berbagai hal.

Di samping itu, dengan berlakunya era Industrial Revolution 4.0 and beyond ${ }^{*}$ SDM

\footnotetext{
2 Menteri Perencanaan Pembangunan Nasional/ Kepala Bappenas, 2019, "Sosialisasi Visi Indonesia 2045", Jakarta, 8 Januari 2019

${ }^{3}$ Dadang Solihin, 2018, "Positioning Organisasi Kepemudaan menghadapi Fenomena VUCA pada Era Revolusi Industri 4.0”, https://www.slideshare.net/DadangSolihin/positioning-organisasi-kepemudaanmenghadapi-fenomena-vuca-pada-era-revolusi-industri-40, diakses 6 Juni 2019

${ }^{4}$ Dadang Solihin, 2018, "Peluang dan Tantangan Pendidikan Tinggi Indonesia di Era Revolusi Industri 4.0", https://www.slideshare.net/DadangSolihin/peluang-dan-tantangan-pendidikan-tinggi-indonesia-di- erarevolusi-industri-40-94694825, diakses 10 Juni 2019
} 
perencana yang profesional dituntut pula untuk memiliki enam kemampuan tambahan, yaitu:

1. Complex Problem Solving, yaitu kemampuan untuk memecahkan masalah yang asing dan belum diketahui solusinya di dalam dunia nyata.

2. Social Skill, yaitu kemampuan untuk melakukan koordinasi, negosiasi, persuasi, mentoring, kepekaan dalam melaksanakan proses perencanaan melalui penggunaan emotional intelligence.

3. Process Skill, yaitu kemampuan yang terdiri dari: active listening, logical thinking, dan monitoring self and the others.

4. System Skill, yaitu kemampuan untuk dapat melakukan judgement dan keputusan dengan pertimbangan cost-benefit serta kemampuan untuk mengetahui bagaimana sebuah sistem dibuat dan dijalankan.

5. Digital Skill, yaitu kemampuan untuk mencari, menilai, memanfaatkan, membagikan, dan menciptakan konten menggunakan teknologi informasi dan Internet.

6. Cognitive Abilities, yaitu kemampuan yang antara lain terdiri dari: Cognitive Flexibility, Creativity, Logical Reasoning, Problem Sensitivity, Mathematical Reasoning, dan Visualization.

Saat ini negara kita sedang menghadapi pengakhiran tahapan RPJPN 2005-2025 serta penetapan strategi pelaksanaan dan penjabaran Visi Indonesia 2045. Untuk itu, SDM perencana yang profesional harus ditingkatkan kualitasnya sehingga memiliki sederet kemampuan diatas untuk lebih berperan dalam mengemban tugas mulia yang sangat strategis tersebut.

\subsection{Outline}

Outline penulisan policy paper ini adalah 1). Pendahuluan yang terdiri dari Gambaran Umum, Latar Belakang, dan Outline, 2). Tujuan dan Metode, 3). Permasalahan, 4). Analisis dan Alternatif kebijakan, 5). Rekomendasi, dan 6). Kesimpulan.

\subsection{Tujuan dan Metode}

Tujuan penulisan policy paper ini adalah untuk menemukenali akar permasalahan yang dihadapi dalam meningkatkan peran perencana dalam kerangka penjabaran Visi Indonesia 2045, serta menyusun rekomendasi kebijakan untuk mewujudkan perencana yang profesional.

Adapun metode yang dipergunakan dalam perumusan policy paper ini adalah metode kualitatif sebagaimana yang dijelaskan dalam Pola Pikir Policy Paper dalam gambar 1 berikut. 


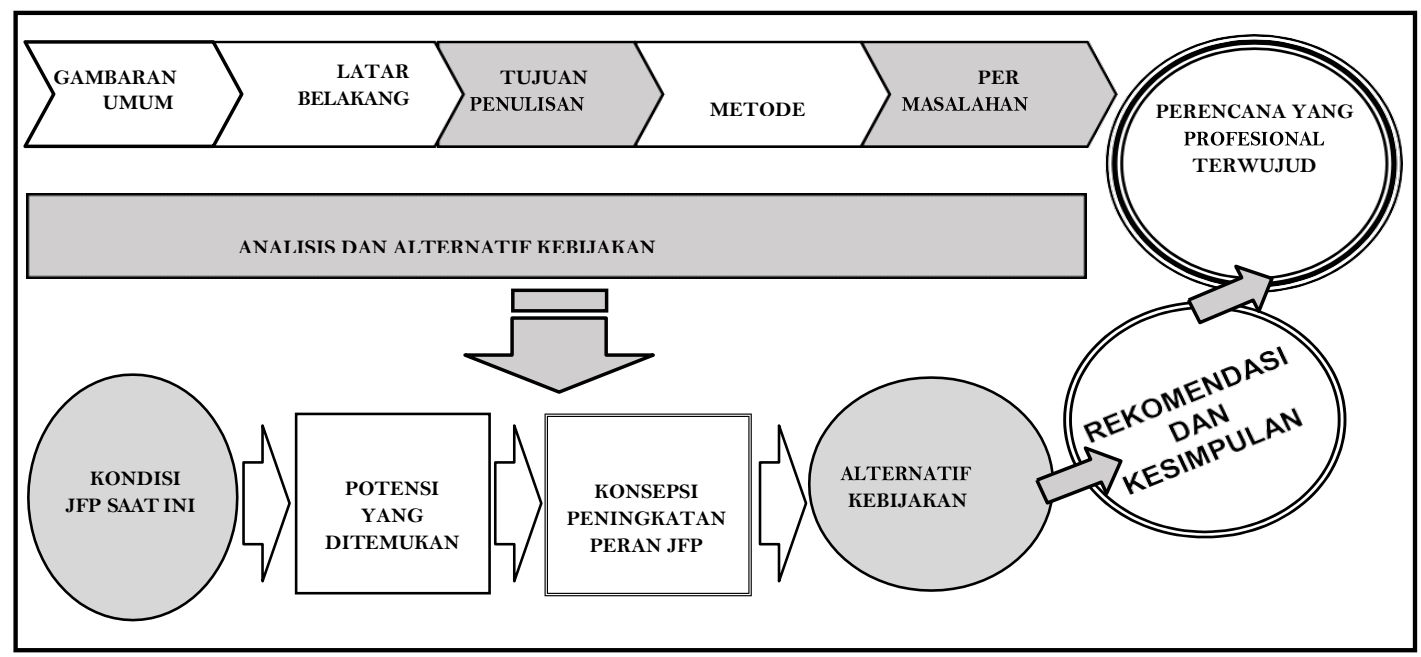

Gambar 1. Pola Pikir Meningkatkan Peran Perencana dalam kerangka

Penjabaran Visi Indonesia 2045

Kondisi JFP Saat Ini diperoleh dari data primer dan sekunder. Data primer diperoleh dari hasil interaksi sehari-hari peneliti dengan para pejabat fungsional Bappenas. Sedangkan Data Sekunder diperoleh dari berbagai publikasi Pusbindiklatren, seperti majalah Simpul, dll.

\subsection{Permasalahan}

Permasalahan yang dihadapi oleh para perencana sebagaimana yang dikemukakan oleh Bastian $2009^{5}$ adalah kurang dipahaminya peraturan JFP, adanya pendapat "minor" terhadap JFP, dan kurangnya komitmen pimpinan. Adapun perumusan permasalahan dalam policy paper ini menggunakan pendekatan $\mathrm{CGI}^{6}$, yaitu Controversy, Gap, dan Inconsistency sebagaimana dijelaskan dalam Tabel 1 berikut.

Tabel 1. Permasalahan dalam Meningkatkan Peran Perencana

\begin{tabular}{|r|l|l|l|l|}
\hline \multirow{2}{*}{ No } & \multicolumn{1}{|c|}{ Issue } & \multicolumn{1}{|c|}{ Controversy } & \multicolumn{1}{c|}{ Gap } & \multicolumn{1}{c|}{ Inconsistency } \\
\cline { 2 - 5 } 1. & $\begin{array}{l}\text { Pemahaman } \\
\text { peraturan } \\
\text { tentang JFP } \\
\text { (is 1) }\end{array}$ & $\begin{array}{l}\text { Peraturan tentang } \\
\text { JFP belum merespons } \\
\text { perubahan jaman (is 1- } \\
\text { co1) }\end{array}$ & $\begin{array}{l}\text { Pengembangan pola } \\
\text { karir JFP (is 1-ga 1) }\end{array}$ & $\begin{array}{l}\text { Arah dan tujuan } \\
\text { AP2I (is 1-in1) }\end{array}$ \\
\hline 2. & $\begin{array}{l}\text { Pendapat } \\
\text { "minor" } \\
\text { terhadap JFP } \\
\text { (is2) }\end{array}$ & $\begin{array}{l}\text { JFP masih dianggap } \\
\text { jabatan buangan (is2- } \\
\text { co2) }\end{array}$ & $\begin{array}{l}\text { Masih ada gap dalam } \\
\text { penugasan fungsional } \\
\text { dan struktural (is2- } \\
\text { ga2) }\end{array}$ & $\begin{array}{l}\text { Belum ada } \\
\text { pemahaman dalam } \\
\text { pemanfaatan JFP } \\
\text { (is2-in2) }\end{array}$ \\
\hline 3. & $\begin{array}{l}\text { Komitmen } \\
\text { pimpinan } \\
\text { terhadap } \\
\text { peran } \\
\text { JFP (is3) }\end{array}$ & $\begin{array}{l}\text { Setelah menjadi JFP } \\
\text { banyak yang mbalelo } \\
\text { (is3-co3) }\end{array}$ & $\begin{array}{l}\text { Prospek JFP di masa } \\
\text { depan (is3-ga3) }\end{array}$ & $\begin{array}{l}\text { Masukan dan } \\
\text { pertimbangan } \\
\text { dari JFP banyak } \\
\text { yang } \\
\text { diabaikan (is3-in3) }\end{array}$ \\
\hline
\end{tabular}

\footnotetext{
5 Danny Bastian, 2009, Kedudukan JFP dalam Struktur Organisasi Pemerintahan, Simpul Perencana Volume 12 Tahun 6, Juli 2009

6 Kuntjoro, Roy, 2019, “Globalisasi dan Pembangunan”, Materi Power Point Pelatihan Fungsional Penjenjangan Perencana Utama Angkatan XI, LPEM FEBUI, 29 April 2019
} 


\section{Analisis dan Alternatif Kebijakan}

\section{Kondisi JFP Saat Ini}

Kondisi JFP saat ini dapat dianalisis dari tiga issue yang dihadapi, yaitu pemahaman peraturan tentang JFP, pendapat "minor" terhadap JFP, dan komitmen pimpinan terhadap peran JFP.

Pemahaman peraturan tentang JFP (is1) ditandai dengan fenomena bahwa peraturan tentang JFP belum merespons perubahan jaman, pengembangan pola karir JFP, dan arah dan tujuan Assosiasi Perencana Pemerintah Indonesia (AP2I). Untuk itu, Bappenas dalam hal ini Pusbindiklatren perlu segera melakukan evaluasi dan revisi peraturan tentang JFP, serta sosialisasi kepada seluruh instansi pengguna terutama tentang kedudukan dan peran JFP dalam proses perencanaan pembangunan ${ }^{7}$.

Peraturan tentang JFP belum merespons perubahan jaman (is 1-co1) adalah permasalahan kontroversi. Oleh karenanya, Pusbindiklatren bersama perguruan tinggi dan $\mathrm{AP}$ 2I perlu merumuskan kembali kompetensi yang benar-benar diperlukan perencana, terutama ditengah berbagai perkembangan: proses perencanaan dan penganggaran, sistem politik dan kepemerintahan, isu-isu globalisasi, krisis ekonomi dan perubahan iklim dunia, dan serta semakin terbatasnya sumber daya;

Masih ada gap dalam pengembangan pola karir JFP (is1-ga1). Sehingga Pusbindiklatren perlu fokus lebih terarah dan sistematis dalam rancang-bangun pengembangan pola karir melalui pelatihan dan non pelatihan, termasuk merevisi desain kurikulum dan standar ujian kompetensi, serta memperjelas susunan dan kedudukan JFP di dalam organisasi pemerintah.

Arah dan tujuan AP2I (is 1-in1) adalah permasalahan inkonsistensi. Harus ada upaya terencana untuk mempercepat pencapaian arah dan tujuan AP2I untuk menjadi organisasi profesi yang handal dan berkewenangan. Dalam hal ini perlu disusun organisasi yang solid, mekanisme sertifikasi, dan penegakan kode etik perencana yang fair, objektif dan berwibawa.

Pendapat “minor” terhadap JFP (is2) ditandai dengan fenomena bahwa JFP masih dianggap jabatan buangan, masih ada gap dalam penugasan fungsional dan strutural, serta belum ada pemahaman dalam pemanfaatan JFP.

JFP masih dianggap jabatan buangan (is2-co2) adalah permasalahan kontroversi. Jabatan struktural dengan berbagai fasilitasnya dengan seketika akan hilang apabila pejabat struktural tersebut diberhentikan dari jabatannya dan dibuang ke fungsional. Bahkan meja kursi untuk sekedar duduk saja bagi seorang yang baru saja menjabat fungsional adalah sesuatu yang sangat sulit didapatkan.

Namun demikian, kesulitan ini tidak menjadi penghambat bagi seorang fungsional untuk terus berkarir. Modal dasar seorang JFP adalah kemampuannya untuk melakukan penelitian dan pengkajian secara komprehensif, holistik, integral, dan tepat waktu, serta memiliki jaringan yang luas dan dekat kepada para pengambil keputusan dan elit kebijakan lainnya. Di samping itu, JFP juga memiliki kontak dengan key persons di kalangan politik, pemerintahan, TNI-Polri, komunitas akademis, dan mass-media.

Masih ada gap dalam penugasan fungsional dan strutural (is2-ga2) ditandai dengan sibuk dan padatnya jadwal kerja sehari-hari yang harus dilaksanakan oleh seorang pejabat struktural, dan di sisi lain seorang JFP terkantuk-kantuk di sudut-sudut ruang 7 Akhir Sebuah Penantian: Penandatanganan Peraturan Presiden Tentang Batas Usia Pensiun JFP, Simpul
Perencana Volume 12 Tahun 6 Juli 200 
kerjanya karena tidak ada penugasan.

Padahal sejatinya JFP memiliki potensi jaringan peneliti, pengkaji, dan nara sumber yang andal dan siap untuk berkolaborasi yang berasal dari dalam dan luar negeri. Di samping itu JFP juga sudah terbiasa untuk memanfaatkan infrastruktur yang dimiliki oleh instansi berupa perpustakaan, jaringan internet, dan langganan journal nasional maupun internasional.

Belum ada pemahaman dalam pemanfaatan JFP (is2-in2) adalah permasalahan inkonsistensi dari tujuan awal dibentuknya JFP pada awal tahun 2000an ${ }^{8}$, yaitu (1) melakukan kegiatan perencanan secara menyeluruh (dari identifikasi permasalahan, sampai penilaian hasil kegiatan), (2) menghasilkan rencana kebijakan makro, sektor dan daerah serta berdampak nasional dan daerah, dan (3) melakukan pemantauan dan evaluasi.

Potensi yang dimiliki JFP yang luar biasa ini dapat dimanfaatkan oleh pemerintah dalam pengambilan kebijakan internasional, regional, dan nasional, diandalkan oleh media dan elit kebijakan di negeri ini, pemanfaatan oleh lembaga legislatif dan eksekutif, serta menjadi referensi yang dibuat untuk penelitian dan analisis dalam publikasi yang ilmiah maupun yang populer.

Komitmen pimpinan terhadap peran JFP (is3) ditandai dengan anggapan bahwa setelah menjadi JFP banyak yang mbalelo, prospek JFP di masa depan, serta banyaknya masukan dan pertimbangan dari JFP yang diabaikan. Untuk para pemangku JFP, peranan dari pimpinan sangat berpengaruh. Pimpinan wajib membina para JFP yang telah ditempatkan, pimpinan juga memantau perkembangan para pejabat fungsional ditempatnya. Seorang pimpinan dapat dimintai pertanggungjawabanya apabila para fungsional ditempatnya tidak mengalami perkembangan atau kemajuan bagi dirinya sendiri ${ }^{9}$.

Anggapan bahwa setelah menjadi JFP banyak yang mbalelo (is3-co3) adalah permasalahan kontroversi. Pada prinsipnya tidak ada perbedaan yang mendasar antara Jabatan Struktural dengan JFP, oleh karena kedua jabatan ini sangatlah berbeda outputnya. Yang diperlukan adalah adanya kewenangan dan kedudukan yang jelas antara struktural dengan JFP. Setelah dia fungsional bukan berarti tidak bisa menjadi struktural kembali, dan setelah menjadi fungsional bukan berarti lepas pekerjaan semuanya dan boleh mbalelo. ${ }^{10}$

Seorang JFP yang profesional dituntut untuk menghasilkan ide-ide dan perumusan kebijakan yang secara jumlah dan kualitas setara world class institution. Produk kajiannya harus out of the box dan outward looking, sehingga menjadi sesuatu yang penting sebagai masukan untuk Musrenbang RPJMN, Musrenbang RKP, untuk dipublikasikan dalam buku, jurnal artikel, makalah kebijakan, dll. Serta tentu saja sebagai masukan bagi perencanaan strategis jangka panjang: 1) Pengakhiran Tahapan RPJPN 2005-2025, dan 2) Penetapan Strategi Pelaksanaan Visi Indonesia 2045.

Prospek JFP di masa depan (is3-ga3) adalah permasalahan gap antara JFP dan struktural. Apakah benar JFP punya prospek yang cukup baik bagi seorang PNS untuk menjadikan jabatan fungsional sebagai pilihan hidupnya? Pilihan untuk menjadi JFP harus dipenuhi persyaratan-persyaratan, antara lain komitmennya, kompetensinya, kejujurannya dan lain-lain. Hal ini harus terus-menerus diuji secara berkala untuk memberikan kualitas jaminan jabatan fungsionalnya.

Bagi seorang PNS, tidak ada masalah ketika ditempatkan dalam posisi apapun dan

\footnotetext{
8 Seminar Nasional Sistem Pembinaan Perencana Pembangunan: Meretas Sejarah Pembinaan Perencana, Simpul Perencana Volume 12 Tahun 6 Juli 2009

9 Wawancara dengan Ir. Arifin Rudiyanto,MSc,PhD, Direktur Pengembangan Wilayah Bappenas, Simpul Perencana Volume 12 Tahun 6 Juli 2009

10 Wawancara dengan Ir. Arifin Rudiyanto, MSc, PhD, 2009
} 
dimanapun hanyalah menjalankan tugas, jadi disini tidak mengenal posisi basah-kering, akan tetapi yang menentukan penghargaan hanya dari perbedaan kinerja. Sebagai contoh apakah adil penghargaan untuk seorang PNS yang bekerja sampai larut malam disamakan dengan seorang PNS yang hanya baca koran, jalan-jalan ke mall atau bahkan datang ke kantor pun tidak tahu apa yang harus dikerjakannya. ${ }^{11}$

Berbagai masukan dan pertimbangan dari JFP banyak yang diabaikan (is3-in3) adalah permasalahan inkonsistensi. Seringkali gagasan yang disiapkan oleh JFP yang memerlukan keputusan struktural akan tetapi tidak diperhatikan dan pertimbangan.

Padahal di luar instansinya, karya JFP banyak yang menjadi rekomendasi yang dipertimbangkan atau diadopsi oleh para pembuat kebijakan, menjadi acuan bagi partai politik, pemerintahan, dan dunia akademik, publikasi atau kutipan dari publikasi di jurnal akademik, pernyataan publik dan penampilan di media cetak dan elektronik yang mempengaruhi perdebatan kebijakan dan pengambilan keputusan.

\section{Potensi yang Ditemukan}

Dari hasil analisis kondisi JFP saat ini ditemukan banyak sekali potensi yang dapat dijadikan modal bagi peningkatan peran perencana dalam kerangka penjabaran Visi Indonesia 2045 serta dalam rangka mewujudkan perencana yang profesional.

Potensi yang ditemukan itu antara lain adalah:

a. Modal dasar seorang JFP adalah kemampuannya untuk melakukan penelitian dan pengkajian secara komprehensif, holistik, integral, dan tepat waktu, serta memiliki jaringan yang luas dan dekat kepada para pengambil keputusan dan elit kebijakan lainnya. Di samping itu, JFP juga memiliki kontak dengan key persons di kalangan politik, pemerintahan, TNI-Polri, komunitas akademis, dan mass-media.

b. JFP memiliki potensi jaringan peneliti, pengkaji, dan nara sumber yang andal dan siap untuk berkolaborasi yang berasal dari dalam dan luar negeri. Di samping itu JFP juga sudah terbiasa untuk memanfaatkan infrastruktur yang dimiliki oleh instansi berupa perpustakaan, jaringan internet, dan langganan jurnal nasional maupun internasional.

c. Potensi yang dimiliki JFP yang luar biasa ini dapat dimanfaatkan oleh pemerintah dalam pengambilan kebijakan internasional, regional, dan nasional, diandalkan oleh media dan elit kebijakan di negeri ini, pemanfaatan oleh lembaga legislatif dan eksekutif, serta menjadi referensi yang dibuat untuk penelitian dan analisis dalam publikasi yang ilmiah maupun yang populer.

d. Karya JFP banyak yang menjadi rekomendasi yang dipertimbangkan atau diadopsi oleh para pembuat kebijakan menjadi acuan bagi partai politik, pemerintahan, dan dunia akademik, publikasi atau kutipan dari publikasi di jurnal akademik, pernyataan publik dan penampilan di media cetak dan elektronik yang mempengaruhi perdebatan kebijakan dan pengambilan keputusan.

\section{Alternatif Kebijakan}

Alternatif Kebijakan bagi peningkatan peran perencana dalam kerangka penjabaran Visi Indonesia 2045 serta dalam rangka mewujudkan perencana yang profesional adalah sebagai berikut:

a. Seorang JFP yang profesional dituntut untuk menghasilkan ide-ide dan perumusan kebijakan yang secara jumlah dan kualitas setara world class institution. Produk kajiannya harus out of the box dan outward looking, sehingga menjadi sesuatu yang

11 Wawancara dengan Rosmananda, SKM., MTP, Fungsional Perencana Bidang Sosial dan Budaya Sub Bidang Kependudukan, Kesehatan BAPPEDA Provinsi Jawa Barat, Simpul Perencana Volume 12 Tahun 6 Juli 2009 
penting sebagai masukan untuk Musrenbang RPJMN, Musrenbang RKP, untuk dipublikasikan dalam buku, jurnal artikel, makalah kebijakan, dll. Serta tentu saja sebagai masukan bagi perencanaan strategis jangka panjang: 1) Pengakhiran Tahapan RPJPN 2005-2025, dan 2) Penetapan Strategi Pelaksanaan Visi Indonesia 2045.

b. Pusbindiklatren bersama perguruan tinggi dan AP2I perlu merumuskan kembali kompetensi yang benar benar diperlukan perencana, terutama ditengah berbagai perkembangan: proses perencanaan dan penganggaran, sistem politik dan kepemerintahan, isu-isu globalisasi, krisis ekonomi dan perubahan iklim dunia, dan serta semakin terbatasnya sumber daya;

c. Pusbindiklatren perlu fokus lebih terarah dan sistematis dalam rancang-bangun pengembangan pola karir melalui pelatihan dan non pelatihan, termasuk merevisi disain kurikulum dan standar ujian kompetensi, serta memperjelas susunan dan kedudukan JFP di dalam organisasi pemerintah.

d. Harus ada upaya terencana untuk mempercepat pencapaian arah dan tujuan AP2I untuk menjadi organisasi profesi yang handal dan berkewenangan. Dalam hal ini perlu disusun organisasi yang solid, mekanisme sertifikasi, dan penegakan kode etik perencana yang fair, objektif dan berwibawa.

\section{Kesimpulan dan Rekomendasi}

\subsection{Rekomendasi}

a. Untuk menghadapi fenomena VUCA, seorang perencana harus visioner, inovatif, dan lincah bergerak.

b. Dengan berlakunya era Industrial Revolution 4.0 and beyond, SDM perencana yang profesional dituntut untuk memiliki enam kemampuan, yaitu: Complex Problem Solving, Social Skill, Process Skill, System Skill, Digital Skill, dan Cognitive Abilities.

c. Potensi yang dimiliki JFP supaya dijadikan modal bagi peningkatan peran perencana dalam kerangka penjabaran Visi Indonesia 2045 serta dalam rangka mewujudkan perencana yang profesional.

\subsection{Kesimpulan}

Ada tiga permasalahan yang dihadapi dalam meningkatkan peran perencana dalam kerangka penjabaran Visi Indonesia 2045, serta dalam menyusun rekomendasi kebijakan untuk mewujudkan perencana yang profesional. Ketiga permasalahan tersebut adalah kurang dipahaminya peraturan JFP, adanya pendapat "minor" terhadap JFP, dan kurangnya komitmen pimpinan.

Untuk mengatasi ketiga permasalahan tersebut, penulis mengusulkan empat buah alternatif kebijakan dan tiga macam rekomendasi untuk dilaksanakan oleh pihak terkait secara terencana dan terkoordinasi.

\section{Referensi}

Dadang Solihin, 2013, "Membangun Lembaga Think Tanks", FGD Deputi Bidang Pengkajian Stratejik Lemhannas-RI di Gedung Astagatra-Jakarta, 2 Desember 2013, https://www.slideshare.net/DadangSolihin/2013-042-lemhannas, diakses 11 Juni 2019

Dadang Solihin, 2018, "Peluang dan Tantangan Pendidikan Tinggi Indonesia di Era Revolusi Industri 4.0", Orasi Ilmiah disampaikan pada Wisuda Magister, Sarjana dan Ahli Madya XIII Gelombang ke 1 Universitas Sangga Buana YPKP Bandung T.A. 2017/2018, Bandung, 21 April 2018, https://www.slideshare.net/DadangSolihin/ 
peluang-dan-tantangan-pendidikan-tinggi-indonesia-di-era-revolusi-industri-4094694825, diakses 10 Juni 2019

Dadang Solihin, 2018, "Positioning Organisasi Kepemudaan menghadapi Fenomena VUCA pada Era Revolusi Industri 4.0”, https://www.slideshare.net/DadangSolihin/ positioning-organisasi-kepemudaan- menghadapi-fenomena-vuca-pada-erarevolusi-industri-40, diakses 6 Juni 2019

Kepmenpan No. 16/KEP/M.PAN/3/2001 tentang Jabatan Fungsional Perencana dan Penetapan Angka Kreditnya

Kuntjoro, Roy, 2019, "Globalisasi dan Pembangunan”, Materi Power Point Pelatihan Fungsional Penjenjangan Perencana Utama Angkatan XI, LPEM FEBUI, 29 April 2019

Majalah Simpul Perencana Volume 12 Tahun 6, Juli 2009

Menteri Perencanaan Pembangunan Nasional/Kepala Bappenas, 2019, "Sosialisasi Visi Indonesia 2045”, Jakarta, 8 Januari 2019. 